\title{
The Institutional Investors' Governance Role on Corporate Overinvestment: A Review Based on Endogeneity
}

MENG Tao

(School of Public Policy \& Management, Tsinghua University, Beijing 100084, China)

\begin{abstract}
With the datum of Chinese A-share listed companies which implemented overinvestment in the year of 2011 and 2012 as research sample, this paper tested the effect of institutional investors on corporate governance from the perspective of endogeneity. The endogenous interrelationship between the institutional investors' shareholding ratio and corporate overinvestment scale is confirmed through the OLS. The further test by TSLS reveals that the participation of institutional investors in corporate governance significantly aggravated the extent of overinvesting and conversely the relatively low level of overinvestment significantly attracted institutional investors. The result suggests that the effect of institutional investors' behavior on corporate governance is double, which means that institutional investors undermined corporate governance efficiency by "voting with hands" and improved it by "voting with feet". The conclusion requires policies be made according with institutional investors' influences to corporate governance and making best use of their advantages.

Keywords: institutional investor; overinvestment; endogeneity problem.
\end{abstract}

\section{INTRODUCTION}

For a long time, a great expectation is always exerted by the policy-making authority on corporate governance level of listed companies and the supervision on the behaviors of institutional investors. As early as January 2002, the China Securities Regulatory Commission (CSRC) clearly stated in the Code of Corporate Governance for Listed Companies in China that "the institutional investors are required to exert an important effect in motivation, supervision and changes of the board and management officers in listed companies". In 2004, the CSRC issued Several Provisions on Strengthening Stockholders' Equity Protection in Public Shares, definitely setting forth the starting of classified voting system. In 2006, Shang Fulin, who was Chairman of the CSRC, said that the CSRC would as always support the development and growth of institutional investors, and proposed five specific supporting measures. The reform-deepening scheme rolled out in 2013 gave priority to the further capital marketization. As main participants in capital market, the institutional investors will certainly play an important role in the next reform of capital market.

However, in reality, the endogeneity in governance effect of institutional investors is generally ignored by business theoretical circles on whether the institutional investors participate and improve corporate governance, or they invest for shareholdings in the companies with higher governance. This possibly causes ambiguous causal relationship between variables. The conclusions drawn in current studies should be re-evaluated in the endogenous research framework on the institutional investors' impact on corporate governance.

At present, the excessive investment impulsion generally exists in listed companies in China, and it harms the interests of stockholders. Thus, both improving supervisory mechanism and reducing excessive investment behavior are two important aspects in improving corporate governance level. For this reason, from the endogenous perspective, it is a research breakthrough evaluating the mutual influence relation between institutional investors and overinvestment behavior in unveiling the governance effect truthfully exerted in reality by China's institutional investors. 
MENG Tao et al. "The Institutional Investors' Governance Role on Corporate Overinvestment: A Review based on Endogeneity"

\section{THEORETICAL ANALYSIS AND HYPOTHESES}

\section{Research Conclusions on Overinvestment}

Many scholars at home and abroad studied the influencing factors and control means of corporate overinvestment. Such foreign scholars as Michael C Jensen ${ }^{[1]}$ (1986), Fazzari S, Hubbard G, Petersen $B^{[2]}$ (1988), Stulz, Rebe $M^{[3]}$ (1990), Hoshi T, Kashyap A, Scharfstein $D^{[4]}$ (1991), Vogt S $\mathrm{T}^{[5]}$ (1994), Blanchard O J, Lopez-de-Silanes F, Shleifer $A^{[6]}$ (1994), Lamont O, Polk $\mathrm{C}^{[7]}$ (2002) explained the corporate overinvestment behaviors mainly from the perspectives of information asymmetry and financing cost, while the scholars at home such as Yang Huajun \& Hu Yiming ${ }^{[8]}$ (2007), Huang Benduo \& Yu Shengdao ${ }^{[9]}$ (2009), Wang Yanchao ${ }^{[10]}$ (2009), Wang Ping \& Sun Shixia $^{[11]}$ (2009), Xu Xiaodong \& Zhang Xitian $^{[12]}$ (2009), Zhang Honghui \& Wang Zongjun ${ }^{[13]}$ (2010), Dai Deming \& Wang Xiaopeng ${ }^{[14]}$ (2011), and Liu Xing \& Lian Jun ${ }^{[15]}$ (2011) more tended to take free cash flow and equity structure as the factors influencing overinvestment. However, the scholars at home and abroad all thought the overinvestment supervising efficiency as an important aspect of measuring the improvement degree of corporate governance

\section{Theoretical Researches on Institutional Investors' Governance Effect}

The institutional investors have an influence on corporate governance. The first one is Voting by Hand, that is, they actively participate and improve corporate decision making in operating management to gain the long-term investment income. Such scholars as Coffee J C ${ }^{[16]}$ (1993), Wahal $S^{[17]}$ (1996), Willard T C, J M Nelson, M S Weisbach ${ }^{[18]}$ (1998), Clyde $\mathrm{P}^{[19]}$ (1997), D D Guercio, Hawkins $\mathrm{J}^{[20]}$ (1999), Davids E P $\mathrm{P}^{[21]}$ (2002), N Hellman ${ }^{[22]}$ (2005), and M Firth ${ }^{[23]}$ (2006) drew inadequately uniform conclusions by studying the effect of corporate governance that institutional investors actively participate in, but a main common viewpoint was concluded that the institutional investors improved the corporate governance.

The other way that the institutional investors have a greater influence on companies is Voting by Foot. If an institution takes less shareholding ratio so that it can't be sufficient to counterbalance substantial shareholders in the companies, then the institution will select the listed companies with higher governance as its investees. By this way, the institution can offer information to the investors in the secondary market so as to affect the government improvement of listed companies indirectly. The studies from the scholars at home and abroad such as Coval J D, Moskowitz T J ${ }^{[24]}$ (1999), Bushee B, C.Noe ${ }^{[25]}$ (2000), Useem M, Bowman E, Myatt, J and Irvine $C^{[26]}$ (1993), Y Grinstein \& R Michaely $^{[27]}$ (2005), Jiang Xiangcai ${ }^{[28]}(2004)^{[28]}$, Xiao Xing \& Wang $\operatorname{Kun}^{[29]}(2005)$, Song Yu \& Yang Hui ${ }^{[30]}$ (2010), Tang Songlian \& Hu Yiming ${ }^{[31]}$ (2011), show that the holding companies selected by institutional investors present outstanding characteristics in corporate government.

\section{Hypotheses in this Paper}

Based on above analyses, it is inferred that because of the intention for maintaining their own interests, the institutional investors either initiatively supervise the managers' behaviors to reduce corporate overinvestment level, or select the companies with relatively perfect supervisory mechanism itself and lower overinvestment level as its shareholding target to reduce their monitoring cost. Both institutional investors' shareholdings and corporate overinvestment level present an endogenous relation of reciprocal causation. Based on this, the following hypotheses are put forth in this paper:

Hypothesis 1: The institutional investors improve the corporate supervisory mechanism directly by the way of voting by hand, and their shareholding ratio has a negative relation with the corporate overinvestment level. 
MENG Tao et al. "The Institutional Investors' Governance Role on Corporate Overinvestment: A Review based on Endogeneity"

Hypothesis 2: The institutional investors select the companies with efficient supervisory mechanism for shareholdings by the way of voting by foot way to improve the corporate supervisory mechanism indirectly, and the corporate overinvestment level has a negative relation with their shareholding ratio.

\section{EMPIRICAL RESEARCH DESIGN}

\section{Source and Screening of Samples}

The empirical study samples to verify hypotheses in this paper included the related data of A-shares listed companies in Shanghai and Shenzhen stock markets during 2011-2012. The corporate overinvestment degree needed to be measured in empirical model, and the data of main samples a year ahead are required to be selected. For this reason, the initial samples were involved in the three years from 2010 to 2012. In addition, the following screening operations were done for the initial samples in order to ensure reliability of empirical conclusions: (1) Excluding the company samples marked with ST, PT and *ST; (2) Excluding the financial and insurance company samples; (3) Excluding the company samples with data missing; (4) Excluding the company samples with a listing time of less than five years; and (5) Excluding the samples in the first $1 \%$ and the last $1 \%$ of scores. After the processing by such standards, total 3848 valid samples were gained. The financial data and governance data related to listed companies came from CSMAR database, and the shareholding ratio data in different types of institutional investors were from WIND database.

\section{Variable Design and Description}

\section{Explaining and Explained Variables}

(1) Institutional investors' shareholding ratio (INST): In the endogenous test method for institutional investors' governance effect in this paper, the institutional investors' shareholding ratio is an endogenous variable, which denotes a proxy of the right to vote in its actively exerting a positive governance effect as an explaining variable. On the other hand, as an explained variable, it indicates that the corporate governance improvement degree is a proxy of influence in the investors' decision making for investment. The empirical study in this paper refers to the ideals of Song $\mathrm{Yu}^{[32]}$ (2009) and Tang Yuejun \& Song Yuanyang ${ }^{[33]}$ (2010), holding the influence of different types of institutional investors on corporate governance is different with their investment philosophies and business practices. Hence, in consideration of the heterogeneity of institutional investors in this paper, the institutional investors are classified into five classes by the classification of WIND database: fund institution (FUND), security institution (SECU), QFII, insurance company (INSU), and social security fund institution (SOCI), respectively studying the governance effect exerted by the different types of institutional investors in their own practices.

(2) Overinvestment (OverInv): The financial index-based method by Richardson [34] (2006) is used for reference for the measurement of overinvestment degree in this paper. Total investment $\left(\mathrm{I}_{\mathrm{T}}\right)$ is decomposed into the maintaining investment $\left(\mathrm{I}_{\mathrm{M}}\right)$ and new investment $\left(\mathrm{I}_{\mathrm{N}}\right)$ first, and then the new investment $\left(\mathrm{I}_{\mathrm{N}}\right)$ is further decomposed into normal expecting investment expenditure $\left(\mathrm{I}_{\mathrm{E}}\right)$ and nonexpecting investment expenditure $\left(\mathrm{I}_{\varepsilon}\right)$, where, total investment $\left(\mathrm{I}_{\mathrm{T}}\right)$ is replaced by the cash flow in corporate investment activity, $\mathrm{I}_{\mathrm{M}}$ is measured by the corporate depreciation and amortization charges, and $\mathrm{I}_{\mathrm{N}}$ can be estimated by structuring the expectation investment model in consideration of some determinant factors for investment. The above measuring overinvestment index can be represented by the following formula:

$I_{T}=I_{M}+I_{N}$

$I_{N}=I_{E}+I_{\varepsilon}$ 
MENG Tao et al. "The Institutional Investors' Governance Role on Corporate Overinvestment: A Review based on Endogeneity"

$$
I_{N t}=\alpha_{0}+\alpha_{1} \text { Growth }_{t-1}+\alpha_{2} \text { Lev }_{t-1}+\alpha_{3} \text { Lnsize }_{t-1}+\alpha_{4} \text { Age } e_{t-1}+\alpha_{5} \text { Cash }_{t-1}+\alpha_{6} \operatorname{Return}{ }_{t-1}+\alpha \text { Indummy }+I_{\varepsilon}
$$

Formula (3) is an expecting model on new corporate investment level. In the model, the determinant factors for investment level are based on some practices of Yang Huajun \& Hu Yiming ${ }^{[8]}(2007)$ and Xin Qingquan, Lin Bin and Wang Yanchao ${ }^{[35]}$ (2007). In the formula, Growth $\mathrm{t}_{\mathrm{t}-1}$ represents the proxy of initial corporate growth opportunity, and it is measured by Tobin' $\mathrm{Q}=$ Total corporate market value/Gross assets book value; $\operatorname{Lev}_{\mathrm{t}-1}$ is the initial corporate asset-liability ratio; Lnsize $_{\mathrm{t}-1}$ is the nature logarithmic value of total initial corporate assets value; Age $_{t-1}$ is the listed year; Cash $_{t-1}$ is the cash holdings of the company, and it can be substituted by initial cash stock balance/Total corporate asset book value; Return $\mathrm{t}_{\mathrm{t}-1}$ is the annualized return of corporate stock in the previous years, and Indummy refers to $0-1$ variables of corporate industry. The residual error $I_{\varepsilon}$ by the OLS multiple regression with above variables being substituted into the formula is the non-expecting investment, and it presents the non-efficiency degree of corporate investment, that is, $I_{\varepsilon}$ is less than 0 , indicating the company has insufficient investment, while $I_{\varepsilon}$ is greater than 0 , indicating the company has overinvestment behavior. The regression result shows that 1793 of 3848 listed company samples have insufficient investment, and the other 2055 listed companies have overinvestment behavior. Such result also demonstrates the non-efficiency behavior of listing corporate investment mainly comes from overinvestment in China. In view of the research objectives in this paper, the 2055 listed companies whose $I_{\varepsilon}$ is greater than 0 are determined as empirical research samples.

\section{Control Variables}

The key point for the empirical research in this paper is to reveal a cause-effect relation between the institutional share-holding behavior and listing corporate overinvestment behavior (that is, which is cause or effect). So the factors that influence both corporate overinvestment and institutional shareselecting behavior should be considered in setting of control variables. For the former, we referred to the research approaches of Michael C Jensen ${ }^{[1]}$ (1986), Fazzari S, Hubbard G \& Petersen B ${ }^{[2]}$ (1988), Hu Jianping \& Gan Shengdao ${ }^{[36]}$ (2007), Yang Huajun \& Hu Yimin ${ }^{[8]}$ (2007), Xu Xiaodong and Zhang Tianxi $^{[12]}$ (2009), and Ye Jianfang, Zhao Shengnan \& Li Danmeng ${ }^{[37]}$ (2012), and set the following variables: free cash flow (FCF), corporate growth opportunity (Tobin'Q), ownership concentration (Top10) and the main corporate business revenue (Reven). For the latter, we gave a comprehensive consideration of the viewpoints from Useem M, Bowman E, Myatt, J \& Irvine $C^{[26]}(1993)$, Bushee ${ }^{[25]}$ (2000), Jiang Xiangcai ${ }^{[28]}$ (2004), Xiao Xing \& Wang Kun ${ }^{[29]}$ (2005), and Song Yu \& Yang Hui ${ }^{[30]}$ (2010), holding the factors influencing the institutions' stock-selecting decision include ownership structure, growth index, risk indexes, scale indexes and industrial indexes of the target company. Accordingly, the following variables are set in this paper: Top 10 shareholders' shareholding ratio (Top10), price earning ratio (Pe), business profit growth rate (Pgrow), annualized volatility (Risk), nature logarithm of total assets (Lnsize) and corporate industry (Indus).

For the estimation of free cash flow, this paper refers to the practices of Richardson ${ }^{[34]}$ (2006), that is, the residual cash amount $=\mathrm{CFO}-\left(\mathrm{I}_{\mathrm{M}}+\mathrm{I}_{\mathrm{E}}\right)$, where $\mathrm{I}_{\mathrm{E}}=\mathrm{I}_{\mathrm{N}}$ (estimated by Formula $\left.(3)\right)-\mathrm{I}_{\varepsilon}($ nonexpecting investment level). The approach of free cash flow by the formula is as follows:

$F C F=C F O-I_{M}-I_{E}$

All variables set for the empirical model in this paper see Table 1.

Table1. Description of model variables

\begin{tabular}{|l|l|l|}
\hline Variable code & Variable name & Definition \\
\hline INST & $\begin{array}{l}\text { Institutional investors' } \\
\text { shareholding ratio }\end{array}$ & $\begin{array}{l}\text { Shareholding ratio by the end of the year in fund (FUND), security } \\
\text { (SECU), QFII, insurance company(INSU), social security fund (SOCI) }\end{array}$ \\
\hline
\end{tabular}


MENG Tao et al. "The Institutional Investors' Governance Role on Corporate Overinvestment: A Review based on Endogeneity"

\begin{tabular}{|c|c|c|}
\hline OverInv & Overinvestment level & $\begin{array}{l}\text { Calculating method: According to estimated } \mathrm{I}_{\varepsilon} \text { by Formulas }(1),(2) \text { and } \\
(3) \text {, the regression result at } \mathrm{I}_{\varepsilon}>0 \text { is divided by total corporate assets }\end{array}$ \\
\hline Top10 & $\begin{array}{l}\text { Ownership } \\
\text { concentration }\end{array}$ & Total sum of Top10 shareholders' shareholding ratio \\
\hline $\mathrm{Pe}$ & Price earning ratio & $\begin{array}{l}\text { Corporate market value of each share/Average post-tax profit each } \\
\text { share }\end{array}$ \\
\hline Pgrow & $\begin{array}{l}\text { Operating } \\
\text { growth rate }\end{array}$ & (current operating profit)/early operating profit*100\% \\
\hline Risk & $\begin{array}{l}\text { Investment company's } \\
\text { share risk }\end{array}$ & $\begin{array}{l}\text { Standard deviation of one-year return on investment for corporate } \\
\text { stock calculated by weekly yield }\end{array}$ \\
\hline Lnsize & Corporate asset size & Nature logarithm of corporate asset book values \\
\hline Indus & $\begin{array}{l}\text { Industrial proxy } \\
\text { variable }\end{array}$ & $\begin{array}{l}\text { 0-1 variable: } 1 \text { if the company belongs to manufacturing; if not, it is } 0 \\
\text { according to CSRC's classification standard. }\end{array}$ \\
\hline FCF & Free cash flow & $\begin{array}{l}\text { Estimating according to Formula (4), and the estimating result is } \\
\text { divided by corporate assets book value. }\end{array}$ \\
\hline Tobin's Q & Tobin's Q value & Total corporate market value/corporate asset book value \\
\hline Reven & Corporate revenue & Corporate business income/Total asset value in corporate books \\
\hline
\end{tabular}

\section{Empirical Research Model}

On the basis of above definition of variables, the following two multiple regression models are designed in this paper, and they are corresponding to the aforesaid two hypotheses respectively:

$$
\begin{aligned}
& \text { OverInv }=\alpha_{0}+\alpha_{1} I N S T+\alpha_{2} F C F+\alpha_{3} \text { Tobin's } Q+\alpha_{4} \text { Top } 10+\alpha_{5} \operatorname{Reven}+\varepsilon \\
& \text { INST }=\alpha_{0}+\alpha_{1} \text { OverInv }+\alpha_{3} P e+\alpha_{4} \text { P grow }+\alpha_{5} \text { Risk }+\alpha_{6} \text { Lnsize }+\alpha_{7} \text { Indus }+\varepsilon
\end{aligned}
$$

The empirical research in this paper mainly confirms actual cause-and-effect relationship between corporate overinvestment degree and institutional investors' shareholding behavior in consideration of their endogeneity. The empirical test is done by two steps: one is the test of one-way causation, and the purpose is to verify if there is a one-way causation between corporate overinvestment degree and institutional investors' shareholding behavior; the test is completed by the ordinary least squares (OLS). The other step is the test of endogenous both-way causation, that is, after the one-way causation is confirmed, which of both corporate overinvestment degree and institutional investors' shareholding behavior is determined as cause or effect finally by the two-stage least squares (TSLS).

Based on the aforesaid theoretical analysis and hypotheses, it is believed that institutional investors actively participate in corporate governance and improve corporate supervisory mechanism from the perspective of their own long-term investment interests, so as to inhibit the overinvestment behavior tendency. In addition, in consideration of saving supervisory cost, the institutional investors can study corporate governance before selecting the investees, and they tend to the listed companies with more perfect shareholding supervisory mechanism, whereas the companies with efficiently supervisory mechanism certainly can't waste cash resources excessively. Thus, it is expected that by whether OLS or TSLS, the regression results of the $\alpha_{1}$ in Formulas (5) and (6) are negative.

\section{EMPIRICAL RESULT ANALYSIS}

\section{Descriptive Statistical Results}

This paper gives a descriptive statistical analysis on partial variables in the model first as shown in Table 2. The average values of investors' shareholding ratio in different types of institutions reflect the imbalance of China's current institutional development level; the fund holdings amount (FUND) is far higher than the ones of other types of shareholding institutions. However, by contrast, China's institutional shareholding ratio made up only $10 \%$ or more, standing in a lower level, while US institutional shareholding ratio accounted for over $70 \%$ by the end of 2007 as a leading investor of securities market. The overinvestment degree (OverIn) in this paper is a result gained by comparison 
MENG Tao et al. "The Institutional Investors' Governance Role on Corporate Overinvestment: A Review based on Endogeneity"

with total corporate assets, and the average quota of $2 \%$ close to total assets indicates China has very serious overinvestment of listed companies; the Top10 shareholders' shareholding ratio comes to over $56 \%$, indicating China's listed corporate equity structure is still in a highly-centralized state, and a large number of enterprises have serious loss in investment operation. The average price earning ratio (Pe) reaches over 73, and its median is only less than 28 , indicating China's listed corporate share price is also presenting a skewed distribution.

Table2. Descriptive statistical result on partial variables

\begin{tabular}{|l|l|l|l|l|l|l|}
\hline Variables & Sample size & Mean value & Median & Minimum & Maximum & Std. Deviation \\
\hline FUND & 2055 & 0.067 & 0.017 & 0 & 0.734 & 0.113 \\
\hline SECU & 2055 & 0.005 & 0 & 0 & 0.227 & 0.014 \\
\hline QFII & 2055 & 0.001 & 0 & 0 & 0.09 & 0.005 \\
\hline INSU & 2055 & 0.006 & 0 & 0 & 0.218 & 0.015 \\
\hline SOCI & 2055 & 0.005 & 0 & 0 & 0.117 & 0.011 \\
\hline OverIn & 2055 & 1.92 & 1.185 & 0.001 & 18.073 & 2.371 \\
\hline FCF & 2055 & 2.38 & 1.494 & -4.387 & 24.582 & 2.854 \\
\hline Top10 & 2055 & 0.562 & 0.573 & 0.036 & 0.981 & 0.169 \\
\hline Pe & 2055 & 73.944 & 27.606 & -457.5 & 1329.573 & 243.562 \\
\hline Pgrow & 2055 & -1.040 & 0.011 & -113.45 & 95.479 & 26.225 \\
\hline
\end{tabular}

Grouping Test Results

Prior to regression analysis, the grouping test was first done from two aspects: institutional investors' shareholding ratio and overinvestment level, preliminarily to confirm whether the endogenous relation of reciprocal causation existed between them. The testing method was to sequence institutional investors' shareholding ratios and overinvestment levels by their separate values. Two groups of subsamples were structured by the first and last values in 10\%: high-ratio shareholding group and lowratio shareholding group as well as high-overinvestment group and low-overinvestment group. The separate $\mathrm{T}$ test was done for the average value of overinvestment levels corresponding to the first subsample group and the average value of institutional shareholding ratios corresponding to the last subsample group, and the testing results are shown in Tables 3 and 4 respectively.

Table3. Grouping test results by institutional shareholding ratio

\begin{tabular}{|l|l|l|l|l|l|l|}
\hline & $\begin{array}{l}\text { Mean value of } \\
\text { FUND } \\
\text { shareholding }\end{array}$ & $\begin{array}{l}\text { Mean value of } \\
\text { SECU } \\
\text { shareholding }\end{array}$ & $\begin{array}{l}\text { Mean value of } \\
\text { QFII } \\
\text { shareholding }\end{array}$ & $\begin{array}{l}\text { Mean value } \\
\text { of } \\
\text { shareholding }\end{array}$ & $\begin{array}{l}\text { Mean value of } \\
\text { SOCI } \\
\text { shareholding }\end{array}$ \\
\hline high-ratio shareholdi-ng group & 1.863 & 1.909 & 1.903 & 1.905 & 1.705 \\
\hline low-ratio shareholdi-ng group & 1.816 & 1.857 & 1.834 & 1.930 & 1.933 \\
\hline T value & -0.193 & -0.216 & -0.325 & 0.105 & 1.044 \\
\hline
\end{tabular}

The data in Table 3 preliminarily indicate a positive supervisory effect of the institutional shareholdings for overinvestment behavior. The results agree with Hypothesis I. Both insurance company (INSU) and social security fund (SOCI) can reduce overinvestment behavior, but they can't pass the test at $10 \%$ significant level, indicating the inhibiting effect is not significant. Other types of institutions, such as securities investment fund (FUND), securities traders (SECU) and qualified foreign institutional investors (QFII), do not reduce overinvestment behavior, but present an aggravating trend though such facilitation falls at $10 \%$ in significance, so they also don't pass the test. In general, the results of grouping test preliminarily present the positive or negative effect of the institutional shareholding involving in corporate governance in overinvestment, with heterogeneity, but it doesn't present a significant effect.

Table4. Grouping test results by overinvestment level

\begin{tabular}{|l|l|lr|lr|ll|ll|}
\hline & $\begin{array}{l}\text { Mean value of } \\
\text { FUND }\end{array}$ & $\begin{array}{l}\text { Mean } \\
\text { of value }\end{array}$ & SECU & $\begin{array}{l}\text { Mean } \\
\text { of }\end{array}$ & $\begin{aligned} \text { value } \\
\text { QFII }\end{aligned}$ & $\begin{array}{l}\text { Mean } \\
\text { of }\end{array}$ & $\begin{array}{r}\text { value } \\
\text { INSU }\end{array}$ & $\begin{array}{l}\text { Mean } \\
\text { of }\end{array}$ & $\begin{array}{l}\text { value } \\
\text { SOCI }\end{array}$ \\
\hline
\end{tabular}


MENG Tao et al. "The Institutional Investors' Governance Role on Corporate Overinvestment: A Review based on Endogeneity"

\begin{tabular}{|c|l|l|l|l|l|}
\hline & shareholding & shareholding & shareholding & shareholding & shareholding \\
\hline high-ratio shareholding group & 0.071 & 0.0057 & 0.001 & 0.005 & 0.002 \\
\hline low-ratio shareholding group & 0.072 & 0.0053 & 0.0012 & 0.007 & 0.003 \\
\hline T value & 0.056 & -0.238 & 0.883 & 1.126 & 0.282 \\
\hline
\end{tabular}

\section{Correlation Test}

In order to reduce the influence of multi-collinearity on empirical results, relevant test should be done for all variables in the model, and Table 5 shows the test results.

Table5. Correlation test results of variables in the model

\begin{tabular}{|l|l|l|l|l|l|l|l|l|l|l|}
\hline & OverIn & Top10 & Tobin'sQ & Pgrow & Risk & Lnsize & Indus & FCF & Pe & Reven \\
\hline FUND & 0.01 & $0.19^{* *}$ & $0.174^{* *}$ & 0.03 & $-0.04^{*}$ & $0.15^{* *}$ & $-0.07^{*}$ & -0.02 & -0.02 & $0.08^{* *}$ \\
\hline SECU & 0.00 & $0.08^{* *}$ & 0.03 & 0.02 & -0.01 & 0.10 & -0.01 & -0.00 & 0.04 & -0.01 \\
\hline QFII & -0.02 & 0.01 & -0.01 & 0.01 & $-0.04^{*}$ & $0.08^{* *}$ & 0.04 & -0.02 & -0.01 & 0.03 \\
\hline INSU & 0.00 & $0.07^{* *}$ & -0.03 & 0.02 & $-0.05^{* *}$ & $0.13^{* *}$ & 0.03 & -0.02 & -0.02 & $0.05^{* *}$ \\
\hline SOCI & -0.02 & $0.15^{* *}$ & 0.03 & 0.01 & -0.01 & $0.07^{* *}$ & -0.03 & -0.02 & 0.00 & $0.05^{* *}$ \\
\hline Top10 & $-0.07^{* *}$ & 1 & -0.01 & $0.05^{* *}$ & 0.03 & $0.23^{* *}$ & $-0.05^{*}$ & $-0.07^{* *}$ & -0.03 & $0.04^{*}$ \\
\hline Tobin'sQ & $-0.10^{* *}$ & $0.05^{* *}$ & 1 & -0.02 & $0.07^{* *}$ & $-0.49^{* *}$ & $-0.09^{* *}$ & 0.00 & 0.00 & $-0.06^{* *}$ \\
\hline Pgrow & 0.01 & $0.05^{* *}$ & $0.21^{* *}$ & 1 & $-0.04^{*}$ & 0.03 & 0.02 & 0.01 & 0.01 & 0.03 \\
\hline Risk & $-0.05^{* *}$ & -0.33 & $0.20^{* *}$ & -0.02 & 1 & $-0.10^{* *}$ & -0.03 & -0.02 & $0.04^{*}$ & $-0.04^{* *}$ \\
\hline Lnsize & $0.13^{* *}$ & $0.18^{* *}$ & $-0.66^{* *}$ & $-0.05^{* *}$ & $-0.22^{* *}$ & 1 & $0.09^{* *}$ & -0.01 & 0.02 & $0.09^{* *}$ \\
\hline Indus & $-0.26^{* *}$ & $-0.06^{* *}$ & $-0.10^{* *}$ & $-0.07^{* *}$ & -0.04 & $0.10^{* *}$ & 1 & $-0.29^{* *}$ & -0.01 & 0.02 \\
\hline FCF & $0.88^{* *}$ & $-0.04^{* *}$ & -0.02 & 0.02 & -0.03 & -0.02 & $-0.23^{* *}$ & 1 & 0.01 & 0.00 \\
\hline Pe & $-0.06^{* *}$ & $-0.09^{* *}$ & $0.27^{* *}$ & 0.01 & $0.18^{* *}$ & $-0.33^{* *}$ & 0.01 & -0.01 & 1 & 0.02 \\
\hline Reven & 0.02 & 0.03 & 0.00 & $0.06^{* *}$ & $-0.05^{* *}$ & $0.06^{* *}$ & 0.00 & 0.02 & $-0.07^{* *}$ & 1 \\
\hline
\end{tabular}

Notes: The data above coefficient 1.00 in the table are the results of Pearson correlation coefficients, and the ones at 1.00 are the results of Spearman correlation coefficients. *: Significant at 10\% (two-tailed test), **: Significant at 5\% (two-tailed test), ***: Significant at 1\% (two-tailed test)

It is seen that there is a very high and big correlation between Tobin's Q and Lnsize, Pe and Lnsize, and Indus and OverInv. In the regression analysis, such variables as Lnsize, Tobin's Q, Pe, and Indus and OverInv are put into a model one by one. Though there is a very high correlation between FUND and Top10 \& Tobin's Q, and Lnsize and Top10, their correlation coefficient is lower than empirical value 0.3 . Thus, they can be put into the model simultaneously. The test results also reflect that there is no correction between institutional shareholding and corporate overinvestment degree, but a very high correlation in some financial and risk indexes, preliminarily indicating the corporate governance is not really concerned by institutions.

\section{Regression Results of Ordinary Least Squares (OLS)}

The regression analysis is completed by two parts in this paper. At first, the cause-and-effect relation of institutional shareholding and corporate overinvestment level is studied irrespective of the influence of endogeneity, to verify whether Hypotheses 1 and 2 can hold water. Tables 6 and 7 show the test results.

Table6. OLS results of governance effect of institutional shareholdings on corporate overinvestment

\begin{tabular}{|c|c|c|c|c|c|}
\hline \multirow[t]{2}{*}{ Variables } & \multicolumn{5}{|c|}{ OverIn } \\
\hline & FUND & SECU & QFII & INSU & SOCI \\
\hline INST & $0.589^{* * *}$ & 0.777 & 0.651 & $3.547^{* *}$ & -0.038 \\
\hline FCF & $0.741^{* * * *}$ & $0.741^{* * * *}$ & $0.740^{* * * * *}$ & $0.740^{* * * *}$ & $0.740^{* * * * *}$ \\
\hline Tobin'Q & -0.023 & -0.015 & -0.015 & -0.014 & -0.015 \\
\hline Top10 & -0.208 & -0.140 & -0.134 & -0.155 & -0.133 \\
\hline Reven & 0.050 & 0.060 & 0.060 & 0.056 & 0.060 \\
\hline F value & 1612.8 & 1605.8 & 1605.5 & 1610.57 & 1605.58 \\
\hline
\end{tabular}


MENG Tao et al. "The Institutional Investors' Governance Role on Corporate Overinvestment: A Review based on Endogeneity"

\begin{tabular}{|l|l|l|l|l|l|}
\hline Adjusted R & 0.797 & 0.796 & 0.797 & 0.798 & 0.796 \\
\hline
\end{tabular}

Note: *: Significant at 10\% (two-tailed test), **: Significant at 5\% (two-tailed test), ***: Significant at $1 \%$ (two-tailed test)

The empirical results in Table 6 are gained by testing of Hypothesis 1, indicating different types of institutional investors' shareholdings exert a positive effect in supervision and inhibit the corporate non-efficient overinvestment behavior irrespective of endogeneity. The empirical results show the influence of institutions on corporate governance is of heterogeneity; the shareholding ratios and corporate overinvestment level pass the significance test at 5\% for securities investment funds institution (FUND) and insurance company (INSU), but other types of institutional shareholdings and overinvestment don't show a sufficient correlation. However, the effect direction of corporate shareholdings of both FUND and INSU on corporate governance is opposite to the expected conditions in Hypothesis 1. The two types of institutional investors don't inhibit corporate nonefficient overinvestment behavior, but aggravate the overinvestment, and play the roles of interest grabbers. On the whole, some institutional investors participate in the corporate governance but exerting a negative effect; some institutional investors' participation doesn't play a significant effect, so that Hypothesis 1 can't be verified.

Table7. OLS results of corporate overinvestment level and institutional share-selecting preference relation

\begin{tabular}{|l|l|l|l|l|l|}
\hline \multirow{2}{*}{ Variables } & \multicolumn{5}{|c|}{ INST } \\
\cline { 2 - 6 } & \multicolumn{1}{|c|}{ FUND } & \multicolumn{1}{|c|}{ QFII } & INSU & SOCI \\
\hline OverInv & $-0.002^{*}$ & -0.00 & -0.00 & 0.00 & $-0.002^{*}$ \\
\hline Pe & 0.000 & 0.00 & -0.00 & 0.00 & 0.00 \\
\hline Pgrow & 0.000 & 0.00 & 0.00 & 0.00 & 0.00 \\
\hline Risk & $-0.017^{* *}$ & -0.00 & $-0.001^{*}$ & $-0.003^{*}$ & -0.070 \\
\hline Lnsize & $0.015^{* * *}$ & -0.001 & $0.003^{* * *}$ & $0.001^{* * *}$ & $0.003^{*}$ \\
\hline Indus & $-0.022^{* * *}$ & 0.00 & 0.00 & 0.00 & -0.00 \\
\hline F value & 11.90 & 2.54 & 2.762 & 6.345 & 7.302 \\
\hline Adjusted R $\mathrm{R}^{2}$ & 0.030 & 0.005 & 0.006 & 0.018 & 0.021 \\
\hline
\end{tabular}

Note: *: Significant at 10\% (two-tailed test), **: Significant at 5\% (two-tailed test), ***: Significant at $1 \%$ (two-tailed test)

Table 7 shows the regression results when we transform the orientation of cause-effect relationship of both corporate overinvestment level and institutional share-selecting preference relation, and study the influence of the mechanism and efficiency in a company supervising overinvestment behavior on the attraction to institutional shareholdings, as well as the verification results. In general, the institutional investors' selection preference is also heterogeneous for the mechanism and efficiency in a company supervising overinvestment behavior, and some institutional investors' behaviors are in line with the expectations in Hypothesis 2. In this regard, the degree of corporate overinvestment presents a significant negative correlation at $10 \%$ with the shareholding ratio of both FUND and SOCI, but this negative correlation doesn't pass the significance test with the shareholding ratio of SECU and INSU at $10 \%$. These results indicate that in consideration of its safety and interests, both FUND and SOCI can take the corporate supervision mechanism and efficiency as important factors in investment decision; the more efficient the corporate supervision mechanism is, the more two institutions tend to investment shareholdings, which reflects their reason in investment. However, the SECU, QFII and INSU do not show obvious investment preference for corporate supervision mechanism and efficiency. The results in Table 7 also indicate that besides corporate governance factor, a company's risk index, size index and industrial index also become institutional investors' main considerations in investment decision-making. The degree of investment risk presents a significant negative correlation with the shareholding ratio of FUND, QFII and INSU, but this negative correlation passes the 
MENG Tao et al. "The Institutional Investors' Governance Role on Corporate Overinvestment: A Review based on Endogeneity"

significance test at $10 \%$. The corporate assets size has a significant positive correlation with the shareholding ratio of other institutions except SECU. Most institutional investors' investment risk avoidance and asset size seeking reflect their reason for investment. By this way, the assumptions in Hypothesis 2 are verified partly.

Based on empirical results in Tables 6 and 7, an innovative finding of the empirical research in this paper is concluded preliminarily that some institutional investors (FUND) affect corporate governance by the two ways of voting by hand and voting by foot, and some institutional investors (INSU and SOCI) make an influence on the corporate governance only by one way of the two ways. The two ways can result in the completely opposite effect of influence on corporate governance: the way of active voting-by-hand participation exerts a devastating effect on corporate governance, while the way of negative voting-by-foot selection can improve the corporate governance. In addition, it is also found that there is an endogenous relation of reciprocal causation between institutional investor's shareholdings and corporate overinvestment behavior, and the relation may affect reliability of OLS regression. Thus, it is necessary to apply the TSLS to further test their relation.

\section{TSLS Regression Results}

The simultaneous equations designed in this paper are agreeing with the aforementioned OLS regression model in excessiveness identification. The parameter evaluation is required by the TSLS for them. Tables 8 and 9 show the TSLS regression results of their reciprocity respectively.

Table8. TSLS results of institutional shareholdings affecting corporate overinvestment

\begin{tabular}{|l|l|l|l|l|l|}
\hline \multirow{2}{*}{ Variables } & \multicolumn{5}{|c|}{ OverIn } \\
\cline { 2 - 6 } & \multicolumn{1}{|c|}{ FUND } & \multicolumn{1}{|c|}{ SECU } & \multicolumn{1}{c|}{ QFII } & \multicolumn{1}{c|}{ INSU } & \multicolumn{1}{c|}{ SOCI } \\
\hline INST & $10.949^{* * * * *}$ & 0.1707 & $400.663^{* * * *}$ & $114.443^{* * * *}$ & $429.593^{* * * *}$ \\
\hline FCF & $0.744^{* * * *}$ & $0.739^{* * *}$ & $0.755^{* * *}$ & $0.751^{* * *}$ & $0.763^{* * *}$ \\
\hline Tobin'Q & $-0.165^{* * *}$ & -0.037 & -0.009 & 0.017 & -0.119 \\
\hline Top10 & $-1.506^{* * *}$ & -0.615 & -0.184 & $-0.800^{* * * *}$ & $-4.048^{* * * *}$ \\
\hline Reven & $-0.119^{* *}$ & 0.078 & -0.037 & -0.068 & -0.311 \\
\hline F value & 494.669 & 430.187 & 378.26 & 494.901 & 85.311 \\
\hline Adjusted $R^{2}$ & 0.571 & 0.626 & 0.127 & 0.304 & 0.292 \\
\hline
\end{tabular}

Note: *: Significant at 10\% (two-tailed test), **: Significant at 5\% (two-tailed test), ***: Significant at $1 \%$ (two-tailed test)

Table9. TSLS results of corporate overinvestment level and institutional shareholding preference

\begin{tabular}{|l|l|l|l|l|l|}
\hline \multirow{2}{*}{ Variables } & \multicolumn{5}{|c|}{ INST } \\
\cline { 2 - 6 } & \multicolumn{1}{|c|}{ FUND } & \multicolumn{1}{|c|}{ SECU } & \multicolumn{1}{c|}{ QFII } & \multicolumn{1}{c|}{ INSU } & \multicolumn{1}{c|}{ SOCI } \\
\hline OverInv & $-1.013^{* * *}$ & -2.450 & $-0.767^{* *}$ & $-0.629^{* *}$ & $-1.362^{* * *}$ \\
\hline Pe & -0.368 & 0.269 & -0.572 & 0.474 & 0.377 \\
\hline Pgrow & 1.027 & 0.108 & 0.259 & 0.348 & 0.604 \\
\hline Risk & -0.517 & -0.472 & -0.852 & $-0.893^{*}$ & -0.870 \\
\hline Lnsize & $0.015^{* * *}$ & -0.001 & $0.013^{* * *}$ & $0.022^{* * *}$ & $0.021^{* * * *}$ \\
\hline Indus & $-0.122^{* * *}$ & 0.063 & 0.723 & 0.361 & $-0.351^{* *}$ \\
\hline F value & 11.90 & 0.617 & 5.62 & 6.881 & 7.663 \\
\hline Adjusted R $\mathrm{R}^{2}$ & 0.131 & 0.021 & 0.106 & 0.116 & 0.135 \\
\hline
\end{tabular}

Note: *: Significant at 10\% (two-tailed test), **: Significant at 5\% (two-tailed test), ***: Significant at $1 \%$ (two-tailed test)

We have the following findings from the results in Tables 8 and 9. In general, compared with abovesaid OLS results, the TSLS regression results have no structural change in consideration of endogeneity. In this regard, some institutional investors actively participate in corporate governance, 
MENG Tao et al. "The Institutional Investors' Governance Role on Corporate Overinvestment: A Review based on Endogeneity"

and get their own income from investment by promoting corporate overinvestment degree, but such the voting-by-hand way is devastating to the corporate governance mechanism. On the other hand, some institutional investors may take the company's supervisory mechanism to overinvestment behavior as a factor for investment decision-making, so that they can attract some institutional investment by the lower overinvestment level. Such voting-by-hand way can improve the corporate governance indirectly.

The difference between TSLS and OLS regression results is mainly reflected in the number of institutional investor types and the values of regression coefficients at a significant level. On one hand, more types of institutional investors, QFII and SOCI shareholding ratio (exclusive of SECU and INSU) has a positive relation with corporate overinvestment degree, and the relation passes the significance test at 5\%. In addition, the regression coefficient increases drastically against the OLS results in the mutual effect relation between institutional investors and corporate overinvestment level. The final conclusion can be drawn in this paper by combining OLS and TSLS regression results as follows: China's institutional investors affect corporate governance and exert different effects by two ways: one is that they actively participate in the governance and make a difference to affect corporate decision making; but such interventional governance behavior for the sake of their own interests may bring down the efficiency of shareholding company's supervisory mechanism. The other way is that they may negatively select the companies with higher corporate governance level as the investees, take the place of institutional investors' governance behavior by their own efficient corporate governance mechanism. As institutional investors' investment decision-making is of guidance quality to some extent in the secondary market, and such selective governance is conducive to indirectly improving the corporate governance level of the whole capital market. The Dual Nature of institutional investors' influence on corporate governance is a main finding in this paper.

\section{Robustness Test}

In order to ensure the robustness characteristics of the empirical results, the robustness test is done from two aspects in this paper. On one hand, the samples are taken in 2009 and 2010 instead of 2011 and 2012. On the other hand, the shareholding-ratio relative number is changed into the absolute number of shareholding quantity for the proxy variables of institutional investors' governance influence in the model. Moreover, in estimation of corporate overinvestment level, the aggregate market value is substituted for total assets for re-estimation. After that, the regression results have not structural change with the aforesaid regression results. So, the regression results in this paper are robust.

\section{CONCLUSIONS AND POLICY SUGGESTIONS}

The endogeneity of institutional investors and corporate governance was always an issue that was less concerned by academic circles at home. The neglect of the endogeneity may make us confused in the governance effect of institutional investors in voting by hand and voting by foot. From the perspective of the endogeneity study in this paper, the empirical test was done for the causal correlation of institutional investors' shareholding behavior and corporate supervisory mechanism efficiency by OLS and TSLS respectively, taking the overinvestment listed companies in Shanghai and Shenzhen A-share markets in 2011 and 2012. Through the test results of OLS, it is found that SECU and INSU shareholding behavior has a statistically significant positive influence on corporate overinvestment degree. In return, the lower corporate overinvestment level could exert the significant attraction to both INSU and SOCI. So the further OLS and TSLS regression results have no essential influence on the conclusions in this paper, but besides SECU and INSU, it is also found QFII and SOCI have a 
MENG Tao et al. "The Institutional Investors' Governance Role on Corporate Overinvestment: A Review based on Endogeneity"

statistically significant facilitation to the corporate overinvestment behavior. The similar changes also occur in the converse relation: The higher corporate overinvestment level not only results in the exclusion of SECU and INSU and statistical reduction of QFII and INSU investment shareholdings, but also TSLS regression coefficient increase a lot against the OLS.

The final conclusion can be drawn in this paper by combining OLS and TSLS empirical results, and China's most institutional investors affect corporate governance in dual nature. On one hand, they participate in the corporate governance actively, and make a difference to affect corporate decisionmaking by voting by hand and support the corporate investment scheme. As there is no enough reason in China's secondary market, the listed companies' investment-related information often brings the hints for companies to earn future interests. This is beneficial to raising the listed company's share price and institutional investors' earnings, but weakens efficiency of supervisory mechanism and aggravates the company's overinvestment level so as to damage the shareholders' interests. On the other hand, the institutional investors can select listed companies with relatively perfect supervisory mechanism to invest, so that they can reduce their own corporate supervising cost. This investment way can provide the investors in the secondary market with the constructive references and instructions on corporate governance information owing to the investment leading effect in the secondary market. By this, the corporate governance level of the whole capital market can be improved indirectly.

The research conclusions in this paper are of significance of reference for policy makers to regularize institutional investors' behavior. The dual nature of institutional investors' governance effect also requires the policies to be formulated from two aspects. On one hand, China's most institutional investors consider the corporate governance degree when they select shareholding objects, so that they can invest reasonably. This is helpful to improve investors' reasoning investment in China's whole capital market. Thus, the policy-making authority should encourage the institutional investors' reasoning share-selecting behavior. On the other hand, the investors' governance effect is of dual nature; the institutional investors tend to do some deeds to damage shareholder interests. Thus, the policy-making authority should take supervisory measures for the institutional shareholding process to prevent the investors doing the deeds to damage shareholders for the sake of seeking their own interests. Besides, the policy-making authority can make institutional regulations on institutional investors' shareholding period, because a certain time is required to realize a series of process: corporate governance improvement-corporate performance improvement-development and understanding of investors and rise of corporate market price in the secondary market — earnings on investment for institutional investors. Otherwise, the investors more tend to enter or get out of stock markets frequently, and conduct opportunistic operation by making up all kinds of information and concepts. In short, the policy-making authority should adopt good points and avoid shortcomings in system designing, that is, it should encourage institutional investor to select shares reasonably, and facilitate institutional investors to play an active role in corporate governance.

\section{REFERENCE}

[1] Michael C Jensen. Agency Costs of Free Cash Flow, Corporate Finance, and Takeovers [J]. American Economic Review, 1986(2): 323-329.

[2] Fazzari S, Hubbard G, Petersen B. Financing Constraints and Corporate in Investment [J]. Brookings Papers on Economic Activity, 1988(1): 141-206.

[3] Stulz, Rebe M. Managerial Discretion and Optimal Financing Policies [J]. Journal of Finance Economic, 1990 (1): 3-27. 
MENG Tao et al. "The Institutional Investors' Governance Role on Corporate Overinvestment: A Review based on Endogeneity"

[4] Hoshi T, Kashyap A, Scharfstein D. Corporate Structure, Liquidity, and Investment: Evidence from Japanese Industrial Groups [J]. The Quarterly Journal of Economics, 1991(1): 33-60.

[5] Vogt S T. The Cash Flow/Investment Relationship: Evidence from U.S. Manufacturing Firms [J]. Financial Management, 1994(2): 3-20.

[6] Blanchard O J, Lopez-de-Silanes F, Shleifer A. What do firms do with cash windfalls? [J]. Journal of Financial Economics, 1994(3): 337-360.

[7] Lamont O, Polk C. Does diversification destroy value? Evidence from the industry shocks [J]. Journal of Financial Economics, 2002(63): 51-77.

[8] Coffee J C. Liquidity Versus Control: The Institutional Investor as Corporate Monitor [J]. Columbia Law Review, 1991(6): 1277-1368.

[9] Wahal S. Public pension fund activism and firm performance [J]. Journal of Financial and Quantitative Analysis, 1996 (31): 1-23.

[10] Willard T C, J M Nelson, M S Weisbach. The Influence of Institutions on Corporate Governance Through Private Negotiations: Evidence From TIAA-CREF [J]. Journal of Finance, 1998(4): 1335-1361.

[11] Clyde P. Do institutional shareholders police management? [J]. Managerial and Decision Economics, 1997(1): 1-10.

[12] D Guercio, Hawkins J. The motivation and impact of pension fund activism [J]. Journal of Financial Economics, 1999(52): 293-340.

[13] Davids E P. Institutional Investors, Corporate Governance and the Performance of the Corporate Sector [J]. Economics Systems, 2002 (5):203-229.

[14] N Hellman. Can We Expect Institutional Investors to Improve Corporate Governance? [J]. Scandinavian Journal of Management, 2005 (3): 293-327.

[15] M Firth. The impact of institutional stockholders and managerial interests on the capital structure of firms [J]. Managerial and Decision Economics,2006(16): 167-175.

[16] Coval J D, Moskowitz T J. Home Bias at Home: Local Equity Preference in Domestic Portfolios [J]. The Journal of Finance, 1999(6): 2045-2073.

[17] Bushee B, C Noe. Corporate Disclosure Practices, Institutional Investors, and Stock Return Volatility [J]. Journal of Accounting Research, 2000(38): 171-202.

[18] Useem M, Bowman E, Myatt J, Irvine C. US Institutional Investors Look at Corporate Governance in the 1990's [J]. European Management Journal, 1993(11): 175-189.

[19] Y Grinstein, R Michaely. Institutional Holdings and Payout Policy [J]. Journal of Finance, 2005(60): 1389-1426.

[20] Richardson S. Overinvestment of Free Cash Flow [J]. Review of Accounting Studies, 2006(11): 159-189. 